\title{
PERAN PELAYANAN ADMINISTRASI KEUANGAN PADA YAYASAN AMAL JAYA DI MASJID RAYA BINTARO
}

\author{
Oleh : Siti Zubaidah, SE, S.Pd.I, M.Pd.I \& Yeni Yulianti
}

Dosen Prodi Sekretari Universitas Pamulang

sitizubaidah49@ymail.com

\begin{abstract}
Abstrak
Tujuan dari penulisan ini adalah untuk mengetahui peran pelayanan adminsitrasi keuangan pada Yayasan amal Jaya di Masjid Raya Bintaro. Berdasarkan pengelolaan data, pengetahuan deskripsi dan pembahasan data tentang peran pelayanan adminsitrasi keuangan, maka penulis dapat menyimpulkan bahwa pelayanan adminsitrasi keuangan sangat penting dalam memberikan pelayanannya. Pada era globalisasi ini administrasi merupakan kegiatan atau usaha untuk membantu, melayani, mengarahkan, atau mengatur semua kegiatan di dalam mencapai suatu tujuan.

Administrasi merupakan totalitas sistem yang terdiri atas subsistem dengan berbagai atribut yang berkaitan, saling ketergantungan, saling berhubungan, dan saling memengaruhi sehingga keseluruhannya merupakan suatu kebulatan yang utuh dan mempunyai tujuan tertentu. Suatu sistem merupakan subsistem dari sistem yang lebih besar. Tantangan adminsitrasi keuangan adalah bagaimana cara memberikan pelayanan yang lebih optimal bagi pelanggan, sehingga pelanggan dapat merasakan kepuasan pada pelayanan adminsitrasi keuangan yang diberikan.
\end{abstract}

Kata Kunci : Peran Pelayanan Administrasi Keuangan

\section{PENDAHULUAN}

\section{A. Latar Belakang}

Dalam peran pelayanan administrasi keuangan merupakan suatu kegiatan atau urutan kegiatan pada suatu usaha yang dilakukan oleh Yayasan Amal Jaya Masjid Raya Bintaro untuk memberikan bantuan dan kemudahan pada masyarakat yang mempunyai kepentingan atau tujuan sesuai dengan aturan pokok dan tata cara yang telah ditetapkan. Dari pengertian diatas tersirat bahwa suatu pelayanan administrasi keuangan pada dasarnya melibatkan dua pihak yang saling berhubungan yaitu Organisasi pemberi pelayanan disuatu pihak dan masyarakat sebagai penerima pelayanan di pihak lainnya. 
Jika Organisasi mampu memberikan pelayanan yang optimal dan memenuhi tuntutan dari masyarakat maka dapat dikatakan organisasi tersebut telah mampu memberikan pelayanan yang memuaskan kepada masyarakat pelaksanaan pelayanan administrasi keuangan pada kantor atau Sekretarisat Yayasan Amal Jaya Masjid Raya Bintaro melalui penataan pelayanan administrasi dalam prosedur Administrasi penerimaan dan penyerahan.

Dalam penerimaan seseorang menerima dari berbagai administrasi seperti penerimaan Zakat Fitrah, Fidyah, Zakat Maal, Zakat Penghasilan, Infaq Anak Yatim, Wakaf Tunai, Infaq Shodaqoh, Administrasi keuangan Taman Pendidikan Al-Qur'an dan dari berbagai Administrasi Keuangan Ruang Serba Guna. Masyarakat yang memiliki niat atau suatu tujuan tertentu kepada Yayasan Amal Jaya Masjid Raya Bintaro. Dalam penataan penyerahan penerimaan Administrasi keuangan menyerahkan kepada bagian Accounting yang melakukan pembagian dalam berbagai administrasi yang di terima.

Dengan demikian upaya meningkatkan pelaksanaan pelayanan diperlukan upaya sungguhsungguh agar diharapkan dapat tercapai dan menjaga Amanat masyarakat yang dititipkan kepada Yayasan Amal Jaya Masjid Raya Bintarodalam Amanat Administrasi masyarakat melalui pemberian Zakat Infaq dan Shodaqoh (ZIS) diprosedurkan dan disalurkan kepada dhuafa sekitar Bintaro, Anak Yatim dan Bantuan bencana di Indonesia.

Kondisi yang ditemukan pada Yayasan Amal Jaya Masjid Raya Bintaro menunjukkan bahwa pelayanan Administrasi keuangan belum Efektif mampu memperbaiki Peran dan Mekanisme penyelenggaraan Aktivitas di kantor ini terkait dengan lambatnya Peran Pelayanan di karenakan masalah kurangnya pegawai, lambatnya penyelenggaraan pelayanan kepada Masyarakat masjid. Sebagian pegawai belum menguasai teknologi dalam hal pengoperasian Komputer.

Lambatnya proses komunikasi dan Fasilitas pelayanan yang masih kurang dan sebagainya merupakan Fenomena-fenomena yang kerap kali mewarnai proses hubungan antara Masyarakat berkaitan dengan Peran pelayanan Hal Ini memberi Isyarat bahwa Kajian dan analisis masalah untuk diteliti khususnya yang dilakukan pada Yayasan Amal Jaya Masjid Raya Bintaro Jaya. Berdasarkan uraian diatas, maka penulis mencoba ingin memberikan gambaran mengenai bagaimana peran pelayanan administrasi keuangan dan untuk memecahkan masalah yang terjadi dengan mengambil judul "Peran Pelayanan Administrasi Keuangan Pada Yayasan Amal Jaya di Masjid Raya Bintaro". 


\section{B. Identifikasi Masalah}

Berdasarkan latar belakang tersebut, maka permasalahan yang dapat di identifikasikan dalam penulisan ini adalah:

1. Pelayanan Administrasi Keuangan pada Yayasan Amal Jaya di Masjid Raya Bintaro sudah dilaksanakan dengan cukup baik, akan tetapi masih banyak donatur yang komplain karena masalah pencatatan administrasi keuangan.

2. Prosedur pencatatan adminstrasi keuangan pada Yayasan Amal Jaya di Masjid Raya Bintaro sudah cukup baik, akan tetapi masih banyak kesalahan dalam pencatatan administrasi keuangan.

3. Prosedur pengelolaan administrasi keuangan pada Yayasan Amal Jaya di Masjid Raya Bintaro, sudah cukup baik, akan tetapi masih banyak kendala yang ditemukan pada saat pencatatan di laporan pembukuan.

\section{Perumusan Masalah}

Berdasarkan identifikasi masalah di atas, penulis akan merumuskan masalah sebagai berikut :

1. Bagaimana cara mengatasi komplain dari para donatur Yayasan Amal Jaya?

2. Bagaimana cara pencatatan administrasi keuangan yang baik pada Yayasan Amal Jaya ?

3. Bagaimana cara pengelolaan administrasi keuangan dan prosedur pencatatan laporan pembukuan pada Yayasan Amal Jaya?

\section{PEMBAHASAN}

\section{A. Pengertian Pelayanan}

Pelayanan dalam hal ini sangat erat kaitannya dengan hal pemberian kepuasaan terhadap pelanggan, pelayanan dengan mutu yang baik dapat memberikan kepuasaan yang baik pula bagi pelanggannya, sehingga pelanggan dapat lebih merasa diperhatikanakan keberadaanya oleh pihak perusahaan.

Menurut Daft, Richarsd L (2006: 45) Pelayanan merupakan suatu proses pemenuhan kebutuhan pelanggan melalui aktivitas fisik yang sifatnya pribadi sebagai 
manusia dan administrasi yang diberikan oleh petugas pelayanan secara langsung yang bertujuan guna mencapai kepuasan pelanggan sebab tujuan utama dari pelayanan adalah untuk menghasilkan nilai tambah bagi instansi.

Sedangkan menurut Moenir ( 2005 : 47 ) Menjelaskan bahwa pelayanan adalah proses pemenuhan kebutuhan melalui aktivitas orang lain secara langsung. Dari beberapa uraian di atas dapat ditarik kesimpulan bahwa pelayanan adalah serangkaian kegiatan yang bersifat tidak kasat mata dan melibatkan upaya manusia atau peralatan lain untuk membantu orang lain agar pekerjaan tersebut dapat berjalan dengan lancar sesuai dengan ketentuan yang berlaku serta dapat memberikan kepuasan kepada pelanggan.

Dalam penyelenggaran pelayanan publik juga diperlukan upaya transparansi yang merupakan pelaksanaan tugas dan kegiatan yang bersifat terbuka bagi masyarakat dari proses kebijakan, perencanaan, pelaksanaan dan pengawasan/pengendaliannya, serta mudah diakses oleh semua pihak yang membutuhkan informasi.

\section{B. Jenis-Jenis Pelayanan}

Pelayanan yang diperlukan manusia pada dasarnya ada dua jenis yaitu:

1. Layanan fisik yang sifatnya pribadi sebagai manusia.

2. Pelayanan administrasi yang diberikan oleh orang lain selaku anggota organisasi (organisasi massa atau organisasi negara).

Dengan jiwa dan falsafah bahwa pelayanan adalah awal dari sebuah pembelian (bagi pelayan untuk keuntungan) dan pelayanan adalah awal memberdayakan. Perlu dikenali bahwa alur pelayanan dapat dibagi dalam dua bagian yaitu:

1. Pelayanan Internal (bahwa dalam organisasi terdapat proses pelayanan) yang meliputi :

a. Pelayanan vertikal, yakni pelayanan dari pimpinan/manajemen kepada unit atau anggota organisasi.

b. Pelayanan horizontal dan diagonal, yakni pelayanan dari unit/anggota organisasi kepada unit atau anggota organisasi lain.

2. Pelayanan Eksternal, yaitu pelayanan organisasi kepada masyarakat atau di luar organisasi dapat dibedakan menjadi dua, yaitu:

a. Pelayanan makro/managerial, yaitu pelayanan dari organisasi kepada masyarakat luas, organisasi yang tampilannya dapat diukur dari kualitas manajemen organisasi yang bersangkutan. 
b. Pelayanan mikro, yaitu pelayanan organisasi kepada masyarakat diluar organisasi yang tampilannya dapat diukur dari kualitas tampilan fisiknya.

Jenis-jenis pelayanan yang sesuai dengan pelanggan yaitu sebagai berikut:

1. Pelayanan sebelum transaksi, pelayanan pada konteks ini meliputi sistem, struktur dan lingkungan operasional yang ditetapkan sebuah organisasi sebelum terjadi transaksi.

2. Pelayanan saat transaksi, pelayanan pada konteks ini adalah pelayanan yang dirasakan oleh pelanggan selama proses transaksi.

3. Pelayanan setelah transaksi, adalah pelayanan yang dinikmati pelanggan setelah transaksi berlangsung, pelayanan pada konteks ini menurut keakuratan dan ketepatan waktu dalam penyelesaian produk layanan.

\section{Pengertian Pelayanan Prima}

Menurut Suparlan ( $2000: 35$ ), pelayanan adalah usaha pemberian bantuan atau pertolongan kepada orang lain. Baik berupa materi ataupun non materi agar orang lain dapat mengatasi masalahnya sendiri. Sedangkan menurut Moenir ( 2005 : 47 ) menjelaskan bahwa pelayanan adalah proses pemenuhan kebutuhan melalui aktivitas orang lain secara langsung. Pelayanan prima merupakan suatu hal yang sangat penting untuk dilakukan dalam memberikan pelayanan oleh suatu organisasi.

Dalam penerapan pelayanan prima perlu diperhatikan hal-hal yang mendukung penerapan pelayanan prima didalam suatu organisasi. Menurut Maddy ( 2009 : 86 ) pelayanan prima adalah suatu pelayanan yang terbaik dalam memenuhi kebutuhan dan harapan pelanggan. Dengan kata lain, pelayanan prima merupakan suatu pelayanan yang memenuhi standar kualitas, karena dituntut untuk memenuhi semua harapan dan kebutuhan konsumen

Untuk menunjang pelaksanaan pelayanan prima, telah dikembangkan konsep (TQM), yaitu sistem manajemen yang melibatkan manajemen dan pegawai untuk memperbaiki kualitas dan kuantitas proses organisasi agar kebutuhan, keinginan dan harapan pelanggan terpenuhi. 


\section{Tujuan Pelayanan Prima}

Menurut www.bacaanpopuler.com yang diunduh tanggal 20 mei 2017 pukul : 20:19 Tujuan pelayanan prima antara lain sebagai berikut :

1. Untuk memberikan pelayanan yang bermutu tinggi kepada pelanggan.

2. Untuk menimbulkan keputusan dari pihak pelanggan agar segera membeli barang/jasa yang ditawarkan pada saat itu juga.

3. Untuk menumbuhkan kepercayaan pelanggan terhadap pelanggan terhadap barang/jasa yang ditawarkan.

4. Untuk menghindari terjadinya tuntuntan-tuntutan yang tidak perlu dikemudian hari terhadap produsen.

5. Untuk menciptakan kepercayaan dan kepuasan kepada pelanggan.

6. Untuk menjaga agar pelanggan merasa diperhatikan segala kebutuhannya.

7. Untuk mempertahankan pelanggan .

\section{Tujuan dan manfaat pelayanan menurut para ahli adalah sebagai berikut :}

1. Menurut Philip Kotler (2006 : 83) pelayanan adalah setiap tindakan atau kegiatan yang ditawarkan oleh satu pihak ke pihak lain, yang pada dasarnya tidak terwujud dan tidak mengakibatkan kepemilikan apapun. Produksinya dapat dikaitkan atau tidak dikaitkan pada satu produk fisik.Selain itu sikap atau cara karyawan dalam melayani pelanggan agar memuaskan berperan besar dalam menciptakan keunggulan layanan ( service excellence). Keunggulan seperti ini dibentuk melalui pengintegrasian empat pilar yang saling berkaitan erat, yaitu kecepatan, ketepatan, keramahan dan kenyamanan pelayanan. Keunggulan pelayanan tidak bisa terwujud apabila salah satu pilar ada yang lemah. Untuk mencapai tingkat keunggulan layanan setiap karyawan baru memiliki keterampilan khusus, diantaranya memahami produk atau jasa secara mendalam. Penampilan rapih dan menarik, bersikah ramah dan bersahabat, menunjukkan komitmen dan responsivitas dalam melayani pelanggan, dan mampu menanggani keluhan pelanggan secara profesional.

2. Menurut Zeithmal Parasuraman (2006:19) kualitas pelayanan dapat didefinisikan sebagai kualitas pelayanan yang diterima konsumen dinyatakan dalam ukuran besarnya ketidak sesuaian antara harapan dan keinginan konsumen dengan tingkat persepsi mereka. 


\section{Sedangkan manfaat pelayanan terhadap konsumen yaitu :}

1. Pelayanan memperpanjang dasar hidup suatu produk yaitu pelayanan bukan saja bagian yang penting dari suatu produk, tapi juga memberikan pendapat dan keuntungan yang lebih besar melalui dasar hidup suatu produk atau jasa.

2. Pelayanan dapat menambah nilai suatu produk yaitu adalah pelayanan dapat menambah nilai suatu produk secara langsung.

3. Untuk produk-produk yang memerlukan pelayanan sebagai unsur tambahan seperti penghantaran, pemasaran dan garansi, konsumen bersedia menambah bayaran itu asalkan dapat menambah nilai suatu produk.

4. Untuk itu perusahaan harus mengutamakan kualitas pelayanan, sebab kualitas pelayanan dapat menumbuhkan minat konsumen untuk kembali lagi.

\section{E. Fungsi Pelayanan Prima}

Menurut www.bacaanpopuler.com yang diunduh pada 20 mei 2017 pukul : 20:19 Pelayanan prima berfungsi sebagai berikut :

1. Melayani pelanggan dengan ramah, tepat, dan cepat.

2. Menciptakan suasana agar pelanggan merasa dipentingkan.

3. Menempatkan pelanggan sebagai mitra usaha.

4. Menciptakan pangsa pasar yang baik terhadap produk/jasa.

5. Memenangkan persaingan pasar.

6. Memuaskan pelanggan, agar mau berbisnis lagi dengan perusahaan.

7. Memberikan keuntungan pada perusahaan.

\section{F. Pelayanan Prima Berdasarkan A3}

Menurut http://mariyammariya.blogspot.co.id yang diunduh tanggal 20 mei 2017 pukul 22:37 Pelayanan prima berdasarkan A3 adalah kegiatan memberikan pelayanan, pendekatan (attitude), perhatian (attention), dan tindakan (action).

\section{Pelayanan prima berdasarkan pendekatan/attitude}

Keberhasilan bisnis industri jasa pelayanan akan sangat tergantung pada orang-orang yang terlihat didalamnya. Sikap pelayanan yang diharapkan tertanam pada diri para karyawan adalah sikap yang baik, ramah dan penuh simpatik, dan mempunyai rasa memiliki yang tinggi terhadap perusahaan. Jika kalian menjadi karyawan suatu perusahaan, sikap kalian akan menggambarkan perusahaan kalian. Kalian akan 
mewakili citra perusahaan baik secara langsung maupun tidak langsung. Pelanggan akan menilai perusahaan dari kesan pertama dalam berhubungan dengan orang-orang yang terlibat dalam perusahaan tersebut.

Sikap yang diharapkan berdasarkan konsep pelayanan prima adalah:

a. Sikap pelayanan prima berarti mempunyai rasa kebanggaan terhadap pekerjaan.

b. Memiliki pengabdian yang besar terhadap pekerjaan.

c. Senantiasa menjaga martabat dan nama baik perusahaan.

d. Sikap pelayanan prima adalah "benar atau salah tetap perusahaan saya" (right or wrong is my corporate)

\section{Pelayanan prima berdasarkan konsep perhatian / attention}

Dalam melakukan kegiatan layanan, seorang petugas pada layanan industri jasa pelayanan harus senantisa memperhatikan dan mencermati keinginan pelanggan. Apabila pelanggan sudah menunjukkan minat untuk memberi suatu barang atau jasa yang kita tawarkan, segera saja layani pelanggan tersebut dan tawarkan bantuan. Sehingga pelanggan merasa puas dan terpenuhi keinginanya.

Hal-hal yang perlu diperhatikan menyangkut bentuk-bentuk pelayanan berdasarkan konsep perhatian adalah sebagai berikut:

a. Mengucapkan salam pembuka pembicaraan

b. Menanyakan apa saja yang diinginkan oleh pelanggan

c. Mendengarkan dan memahami keinginan pelanggan

d. Melayani pelanggan dengan cepat, tepat dan ramah

e. Menempatkan kepentingan pelanggan pada nomor satu

\section{Pelayanan prima berdasarkan tindakan / action}

Pada konsep perhatian, pelanggan "menunjukkan minat" untuk membeli produk yang kita tawarkan. Pada konsep tindakan pelanggan sudah "menjatuhkan pilihan" untuk membeli produk yang diinginkannya.

Terciptanya proses komunikasi pada konsep tindakan ini merupakan tanggapan terhadap pelanggan yang telah menjatuhkan pilihannya, sehingga terjadilah transaksi jual beli.

Bentuk-bentuk pelayanan prima berdasarkan konsep tindakan adalah sebagai berikut :

a. Mencatat pesanan pelanggan

b. Menegaskan kembali kebutuhan atau pesanan pelanggan 
c. Menyelesaikan transaksi pembayaran pesanan pelanggan

d. Mengucapkan terima kasih diiringi harapan pelanggan datang kembali lagi.

Penerapan pelayanan prima yang dapat memberikan kepuasan kepada kolega atau pelanggan pada dasarnya mempunyai manfaat sebagai berikut:

a. Dapat menciptakan komunikasi yang positif dan harmonis antara perusahaan bisnis dengan kolega dan pelanggan.

b. Dapat mendorong bangkitnya rasa simpatik dan loyalitas dari para kolega dan pelanggan.

c. Dapat membentuk opini publik yang positif, sehingga menguntungkan bagi kemajuan perusahaan

d. Dapat menimbulkan profitabilitas perusahaan, sehingga mendorong dan menghasilkan produk baru yang berkualitas.

e. Dapat membina hubungan yang baik dan harmonis dengan para kolega dan pelanggan.

\section{G. Unsur-Unsur Pelayanan Prima}

Menurut www.ilmu-ekonomi-id.com yang diunduh tanggal 20 mei 2017 pukul 23:00 Pelayanan terbaik merupakan unsur pokok tercapainya pelayanan prima harus memenuhi tiga (3) unsur yaitu:

\section{Cheaper (murah)}

Produk atau jasa yang dipasarkan memang murah tetapi tidak murahan, artinya mendapatkan pangsa pasar dengan harga yang terjangkau sehingga produk atau jasa dapat bersaing dan sukses dipasarkan.

\section{Faster (cepat)}

Kebanyakan konsumen atau pelanggan ingin dilayani dengan cepat, namun dibalik kecepatan dalam melayani harus dilengkapi dengan ketelitian.

\section{Better (baik)}

Setelah produk atau jasa terjangkau serta pelayanan yang tepat, juga harus bersikap baik yaitu baik dalam melayani pelanggan dan baik dalam bersikap.

\section{H. Pengertian Administrasi}

Administrasi merupakan suatu fungsi yang memegangperanan yang sangat penting terhadap tercapainya kelancaran usaha kegiatan, maupun aktivitas yang dilakukan oleh perusahaan/organisasi. Menurut Yusak Burhanuddin (2005 : 11) Istilah administrasi 
diambil dari kata "'ad', dan 'ministra'. Ad mempunyai arti ' "kepada" dan ministra berarti 'melayani', sehingga administrasi diartikan sebagai pelayanan atau pengabdian terhadap subjek tertentu.

Selain itu, kata administrasi juga berasal dari bahasa Belanda. yaitu administateyang artinya kegiatan penyusunan dan pencatatan. Kegiatan ini mencakup kegiatan tulis-menulis, mengirim, dan menyimpan keterangan, dan dikaitkan pula dengan aktivitas administrasi perkantoran yang hanya merupakan salah satu bidang dari aktivitas administrasi yang sebenarnya.

Menurut Daryanto (2006 : 28) Ngalim Purwanto berpendapat bahwa kata ad dalam administrasi mempunyai arti yang sama dengan kata to dalam bahasa Inggris yang berarti " $k e$ " atau "kepada". Kata ministratesama artinya dengan kata toserve atau to conduct yang berarti "melayani', 'membantu', atau "mengarahkan" Dalam bahasa Inggris to administer berarti pula mengatur, memelihara (to look after), dan mengarahkan.

\section{Unsur-Unsur Administrasi}

Menurt Daryanto (2010 : 15) Dalam proses operasional administratif terdapat sejumlah unsur yang saling berikaitan antara satu dengan yang lain. Apabila salah satunya tidak ada, proses operasi administrasi akan terhambat, Unsur-unsur tersebut meliputi hal-hal berikut ini.

1. Organisasi, yaitu wadah bagi segenap kegiatan usaha kerja sama.

2. Manajemen, yaitu kegiatan menggerakkan sekelompok orang dan mengerahkan fasilitas kerja.

3. Komunikasi, yaitu penyampaian berita dan pemindahan ide pikiran dari seseorang kepada yang lainnya agar terwujudnya kerja sama.

4. Kepegawaian, yaitu pengaturan dan pengurusan pegawai atau karyawan yang diperlukan.

5. Keuangan, yaitu pengelolaan segi-segi pembiayaan dan pertanggung jawaban keuangan.

6. Perbekalan, yaitu perencanaan, pengadaan, dan pengaturan pemakaian barang-barang keperluan kerja.

7. Tata usaha, yaitu penghimpunan, pencatatan, pengolahan, pengiriman, dan penyimpanan berbagai keterangan yang diperlukan.

8. Hubungan masyarakat, yaitu perwujudan hubungan yang baik dan dukungan dari lingkungan masyarakat terhadap usaha kerja sama. 


\section{J. Keuangan}

Menurut Grasindo (2015:5) Keuangan merupakan kata berimbuhan dengan kata dasar uang. Bila merujuk pada Kamus Besar Bahasa Indonesia, uang merupakan alat tukar sah yang hanya dikeluarakan oleh pemerintah pada sebuah negara. Uang secara tradisional yaitu sebagai alat tukar yang diterima oleh masyarakat secara umum.

Bentuk uang dapat beragam, ia bisa berupa kertas, perak, emas, maupun logam lainnya. Fungsi uang terutama berlaku dalam pertukaran barang atau jasa. Pengertian uang telah berkembang. Ia tidak lagi harus berupa alat tukar yang tersedia secara fisik. Kini uang bisa berarti apapun yang tersedia dan diterima secara umum dalam pembayaran barang, jasa, kekayaan berharga, hingga hutang.

Salah satu pengertian dikemukakan oleh Ridwan dan Inge. Menurut keduanya, keuangan adalah ilmu sekaligus seni pengelolaan uang yang berpengaruh pada kehidupan individu maupun organisasi. Dalam keuangan berkaitan dengan proses, instrumen, pasar, serta lembaga apapun yang terlibat di dalam perpindahan atau transfer uang, baik antar perorangan, bisnis, maupun pemerintah.

Dalam Kamus Besar Bahasa Indonesia (KBBI) (2008:1766) Uang diartikan: (1) Alat tukar atau standar pengukur nilai (kesatuan hitungan) yang sah, dikeluarkan oleh pemerintah suatu negara berupa kertas, emas, perak, atau logam lain yang dicetak dengan bentuk dan gambar tertentu; (2) harta; kekayaan.

Uang dalam ilmu ekonomi tradisional didefinisikan sebagai setiap alat tukar yang dapat diterima secara umum, Alat tukar itu dapat berupa benda apapun yang dapat diterima oleh setiap orang di masyarakat dalam proses pertukaran barang dan jasa. Dalam ilmu ekonomi modern, uang didefinisikan sebagai sesuatu yang tersedia dan secara umum diterima sebagai alat pembayaran bagi kekayaan berharga lainhya serta untuk pembayaran hutang.

\section{K. Pengertian Laporan Keuangan}

Menurut Grasindo (2015:5) Laporan keuangan (financial statements) merupakan produk akhir dari serangkaian proses pencatatan dan pengikhtisaran data transaksi bisnis. Seseorang akuntan diharapkan mampu untuk mengorganisir seluruh data akuntansi hingga menghasilkan laporan keuangan, dan bahkan harus dapat menginterprestasikan serta menganalisis laporan keuangan yang dibuatnya.

Urutan laporan keuangan berdasarkan proses penyajiannya adalah sebagai berikut : 
1. Laporan Laba Rugi (Income Statement) merupakan laporan yang sistematis tentang pendapatan dan beban perusahaan untuk satu periode waktu tertentu. Laporan laba rugi ini pada akhirnya memuat informasi mengenai hasil kinerja manajemen atau hasil kegiatan operasional perusahaan, yaitu laba atau rugi bersih yang merupakan hasil dari pendapatan dan keuntungan dikurangi dengan beban dan kerugian.

2. Laporan Ekuitas pemilik (Statement of Owner's Equity) adalah sebuah laporan yang menyajikan ikhtisar perubahan dalam ekuitas pemilik suatu perusahaan periode waktu tertentu. Laporan ini sering dinamakan sebagai laporan perubahan modal.

3. Neraca (Balance Sheet) adalah sebuah laporan yang sistematis tentang posisi aset, kewajiban dan ekuitas perusahaan pertanggal tertentu. Tujuan dari laporan ini tidak lain adalah untuk menggambarkan posisi keuangan perusahaan.

4. Laporan Arus Kas (Statement of Cash Flows) adalah sebuah laporan yang menggambarkan arus kas masuk dan arua kas keluar secara terperinci dari masingmasing aktivitas, yaitu mulai dari aktivitas operasi, aktivitas inventasi, sampai pada aktivitas pedanaan/pembiayaan untuk satu periode waktu kas dari seluruh aktivitas selama periode berjalan serta saldo kas yang dimiliki perusahaan sampai dengan akhir periode.

5. Tujuan khusus laporan keuangan adalah menyajikan posisi keuangan, hasil usaha, dan perubahan posisi keuangan lainnya secara wajar dan sesuai dengan prinsip-prinsip akuntansi yang berlaku umum.

\section{Pembahasan}

Kegiatan pelayanan pada Yayasan Masjid Raya Bintaro sendiri sudah baik, dengan memilki sikap ramah tamah yang di berikan oleh karyawan pada para Jamaah maupun donatur Masjid Raya Bintaro. Namun, suatu cara kerja pada pelayanan tidaklah selalu sempurna. Masih banyak Jamaah yang merasa kurang puas terhadap pelayanan yang diberikan oleh karyawan Masjid Raya Bintaro. Adapun cara mengatasi komplain Jamaah yang datang adalah sebagai berikut :

\section{Melakukan sambutan terhadap Jamaah}

Ketika pelanggan atau konsumen baru saja datang, seluruh karyawan terutama bagian resepsionist memberikan sambutan atau sapaan Assalamualaikum, atau menjawab dengan Walaikum salam dan sapaan Selamat pagi, selamat siang dan selamat sore. Pelayanan yang baik dapat dinilai dari citra diri yang baik, jika kita memberikan 
pelayanan yang ramah, maka akan kembali ramah. Kegiatan ini bermaksud untuk memberikan suasana keakraban dan memberikan rasa nyaman terhadap suasanan dan pelayanan diperusahaan maupun kantor.

\section{Memberikan informasi yang dibutuhkan terhadap Jamaah}

Setelah menyambut dengan keramah-tamahan dengan jamaah, karyawan memberikan informasi yang diperlukan dan diinginkan, karyawan yang melayaninya harus memahami terlebih dahulu bisa dikatakan dengan mengajak ngobrol terlebih dahulu.

Sehingga mampu memberikan informasi yang tepat dengan kebutuhan jamaah atau donatur tersebut. Tujuan kegiatan ini bertujuan untuk memberikan rasa nyaman dan keakraban, sehingga tidak terjadi kesalahpahaman dalam mengetahui informasi yang diperlukan oleh Jamaah ataupun konsumen tersebut. Sebagai contoh seorang Jamaah membutuhkan informasi tentang jadwal penggunaan ruang serba guna Masjid Raya Bintaro, diantaranya adalah sebagai berikut:

a. Karyawan dapat membantu mencari informasi yang diinginkan jamaah atau donatur diharapkan untuk dapat menunggu, karyawan melakukan pengecekan tanggal apakah kosong atau sudah padat dalam pemesanan gedung yang diinginkan dalam jumlah pemakaian lain. Setelah itu melakukan pengecekan tanggal, apabila kosong dapat masuk atau menggunan gedung Masjid maupun Aula serba guna.

b. Sedangkan jika terjadi pemadatan jumlah pemakaian gedung yang tidak memungkinkan seorang jamaah atau donatur dapat menggunakan di tanggal yang sama, diarahkan untuk memilih tanggal yang kosong apabila ingin melakukan perubahan pemesanan.

c. Kemudian karyawan memberikan masukan kepada jamaah atau donatur untuk membantu jalannya pemesanan tempat atau gedung.

d. Setelah mendapatkan tanggal yang kosong atau tidak ada digunakan untuk kegiatan lain. Karyawan memberikan ketentuan-ketentuan yang sudah di tetapkan di Masjid atau gedung aula serba guna.

e. Disini jamaah atau donatur harus mentaati ketentuan-ketentuan yang sudah di tentukan oleh masjid untuk penggunaan gedung, agar tidak ada kesalah pahaman atau mist komunikasi terhadap jamaah atau donatur untuk mengetahui peraturan yang ditetapkan masjid atau gedung aula serba guna. 
Dari kedua pelayanan yang diberikan pada Masjid Raya Bintaro, semua dicatat kedalam pembukuan secara lengkap. Salah satunya adalah pencatatan adminsitrasi keuangan. Kegiatan pencatatan administrasi keuangan di Masjid Raya Bintaro, terlebih dahulu kita menanyakan kepada jamaah atau donatur apa yang ingin diperlukan dan untuk pembayaran apa. Terutama untuk donatur anak asuh yang memiliki kerutinan kewajiban yang sudah ditetapkan oleh mereka untuk membantu pembayaran sekolah anak asuh setiap bulan.

Karyawan akan meminta kartu terlebih dahulu sampai bulan apa terakhir dia pembayaran, lalu sebagai seorang admin akan mengecek kembali di data yang sudah tercantum di database admin sama atau tidak kah data yang dimiliki admin dengan donatur, lalu menuliskan kembali ke kartu untuk pembayaran bulan selanjutnya dan memberikan pencatatan berupa kwitansi pembayaran bahwa admin memberikan tanda bukti tertulis di kwitansi bahwa pembayaran sudah diterima dan memberikan keterangan pembayaran anak asuh, bulan apa pembayaran.

Setelah itu admin kembali merekap data dari kwitansi ke database yang dimiliki admin, lalu admin mensetor kwitansi dan pembayaran ke bagian accounting untuk merekap ke laporan keuangan baik pemasukan maupun pengeluaran.

Dari kegiatan pencatatan yang dilakukan seorang admin di Masjid Raya Bintaro memiliki prosedur pencatatan diantaranya :

\section{Prosedur Penerimaan Dana (Zakat, Infaq, Shodaqoh, Wakaf Tunai)}

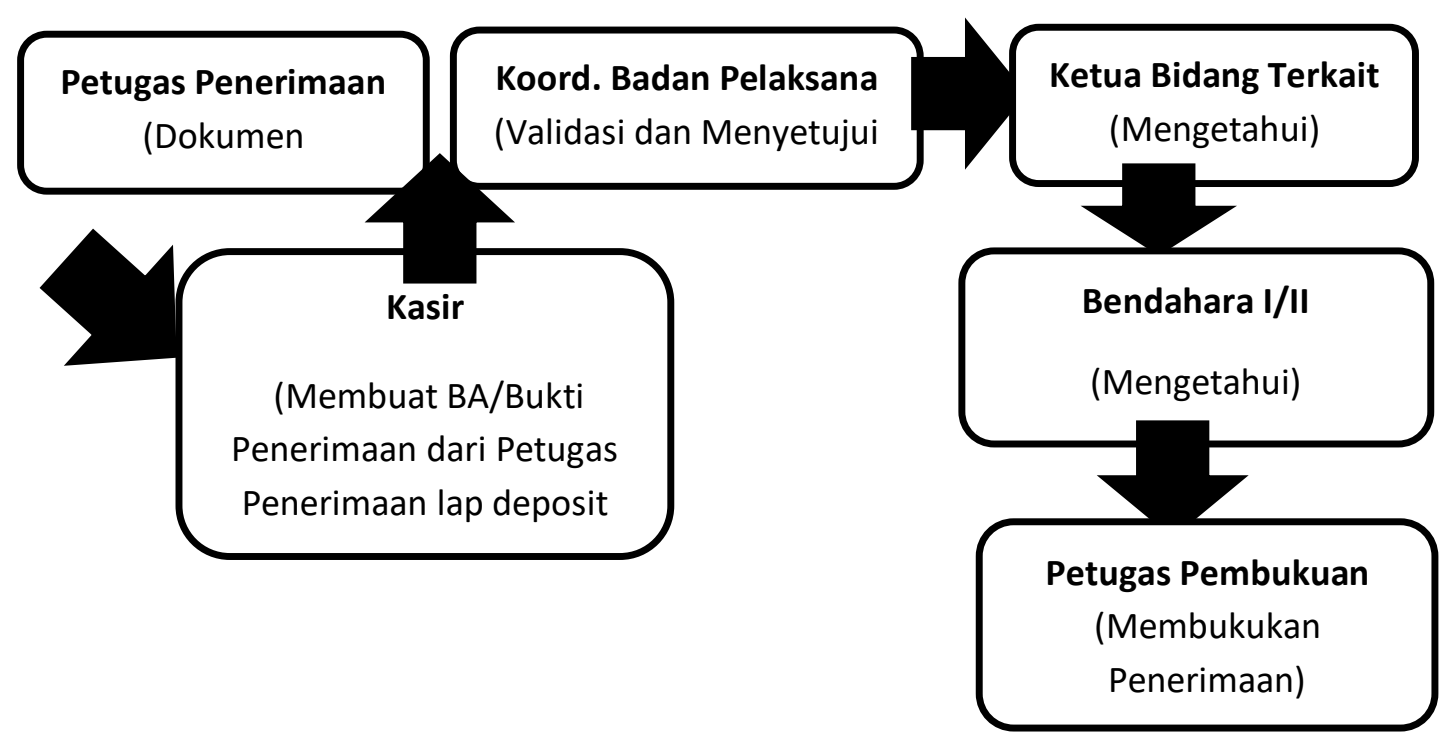

Dari alur prosedur diatas, dapat dirinci kegiatan tersebut adalah sebagai berikut : 
a. Petugas membuat (Bukti Pernerimaan/Form) Kepada Muzaki/Pemberi Infaq/Shodaqoh/Wakif. Bukti Penerimaan/Form Zis dapat digunakan untuk data lampiran bukti penerimaan Zis (Zakat, Infaq, Shodaqoh). Bukti penerimaan tersebut adalah sebagai berikut :

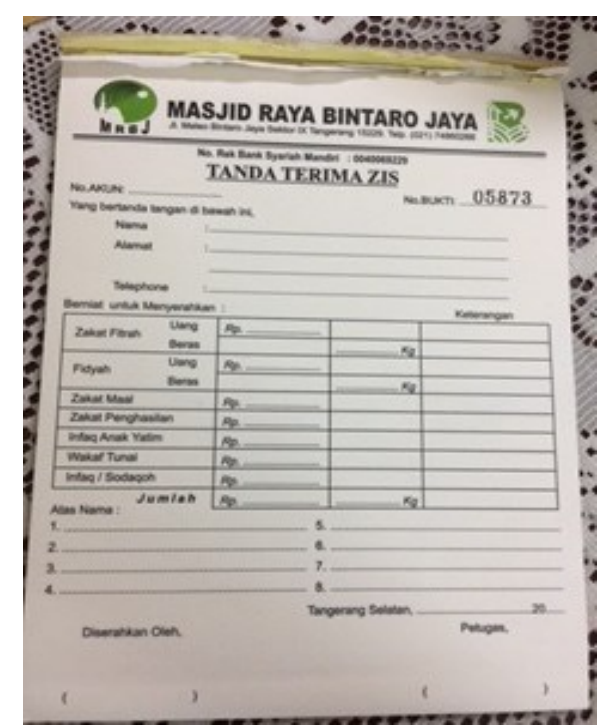

Database daftar anak asuh ini membuktikan bahwa setiap donatur yang wajib setiap bulan membayar untuk infaq anak asuh, apabila donatur menanyakan sampai mana terakhir pembayaran donatur apabila donatur tidak membawa bukti kartu/kwitansi yang kami berikan, dan dapat karyawan melihat di database daftar donatur ini. Data / Gambar Database Donatur Anak Asuh.

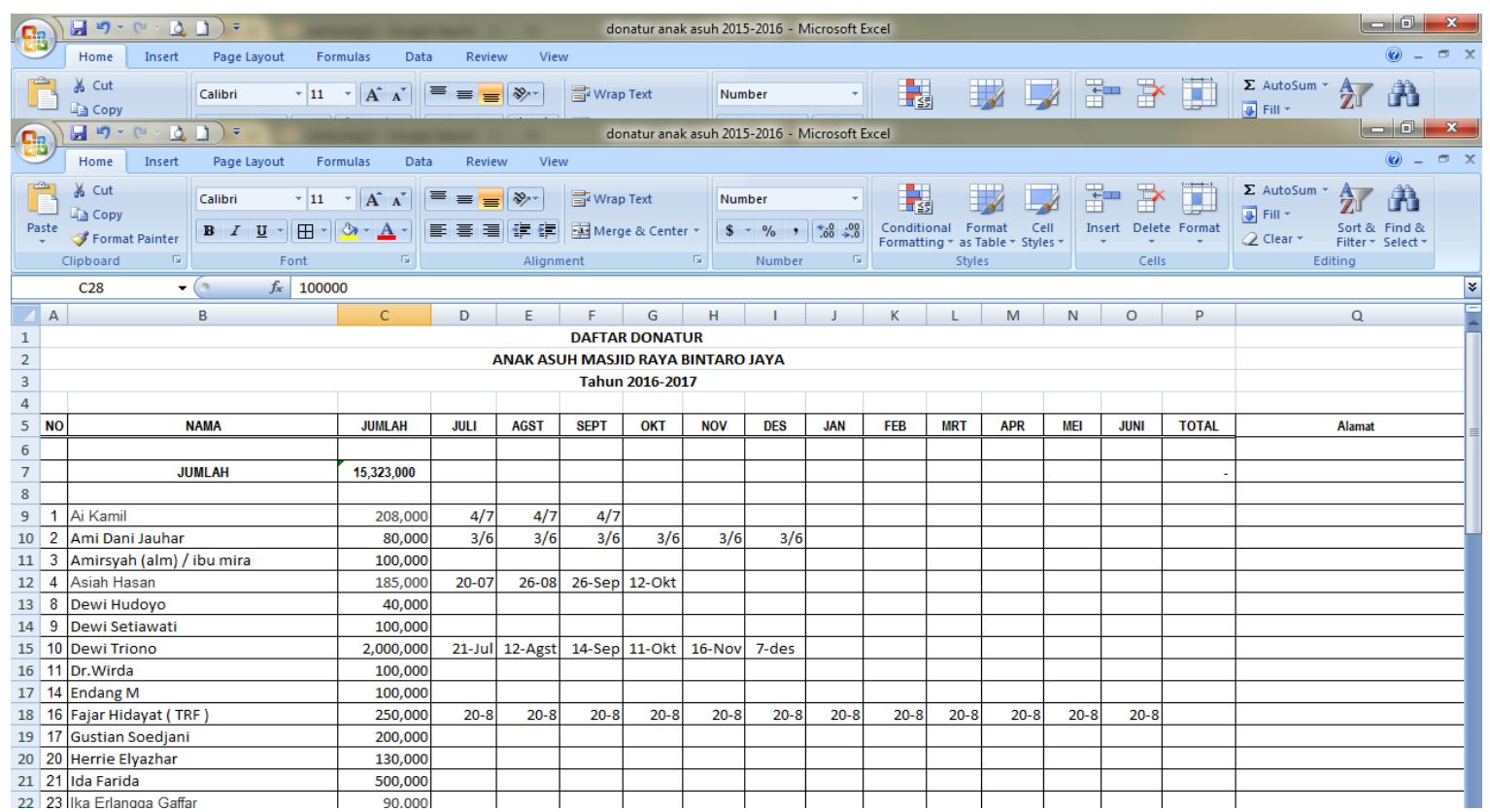


b. Kasir Membuat BA/Bukti Penerimaan lalu Deposit ke Bank. Bukti Penerimaan Bank dapat digunakan untuk pengeluaran suatu kebutuhan operasional Masjid, Pengeluaran Bantuan Dana dari berbagai kegiatan, yang di validasi atau menyetujui melalui Koordinator Badan Pelaksana dan dijalankan kepada Ketua Bidang yang terkait seperti, Bendahara I/II. Adapun format penerimaan bank adalah sebagai berikut :

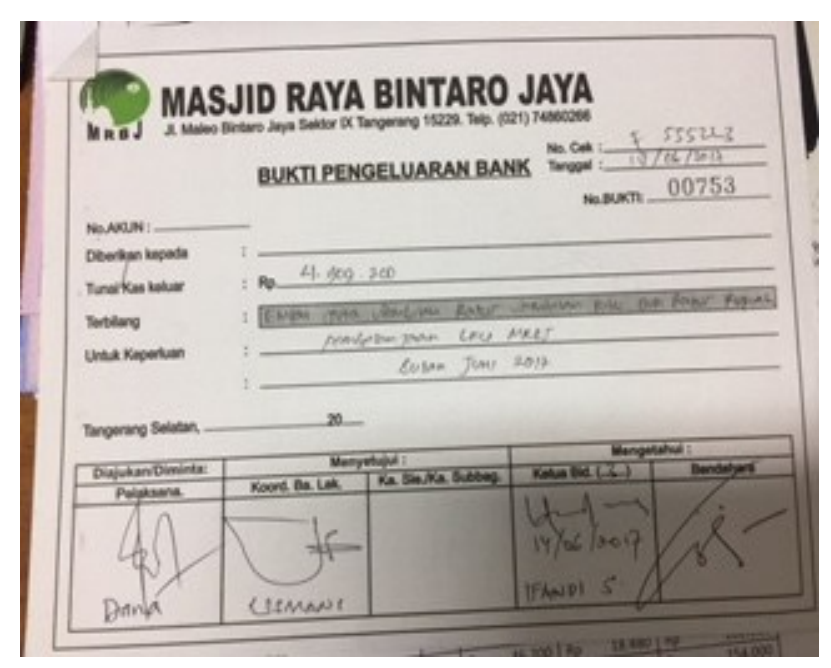

c. Koordinator Badan Pelaksana melakukan Validasi dan menyetujui

d. Ketua Bidang terkait (Mengetahui)

e. Bendahara I/II (Mengetahui)

f. Bendahara I/II (Mengetahui)

g. Petugas Pembukuan (Membukukan Penerimaan)

Setelah prosedur penerimaan dana dari donatur dilakukan, maka admin yang bertugas melakukan pencatatan pembukuan. 


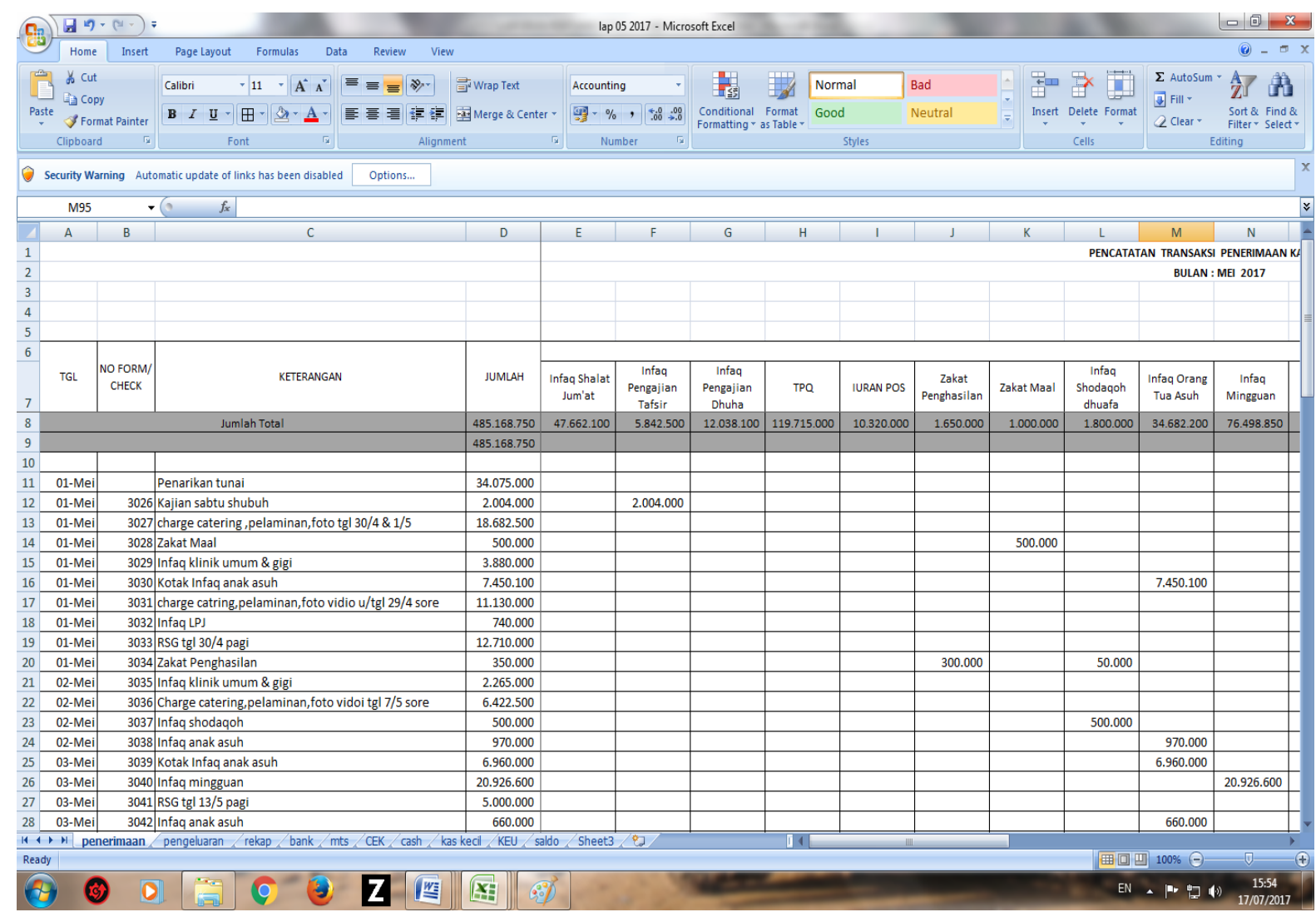

Database pembukuan ini bukti dari penerimaan kas atau penerimaan pemasukan administrasi dari form penerimaan Zakat, Infaq Shodaqoh dan Anak Asuh yang akan dilaporkan ke pengurus setiap bulannya.

\section{KESIMPULAN}

Yayasan Amal Jaya Masjid Raya Bintaro adalah sebuah yayasan yang bergerak dibidang jasa yang melayani berbagai bidang jasa seperti bidang zis (zakat, infaq, sadaqah), bidang pendidikan dan bidang kesehatan. Namun dalam proses pelayanan administrasi hingga suatu cara kerja pada pelayanan tidaklah selalu sempurna.

Masih banyak Jamaah yang merasa kurang puas terhadap pelayanan yang diberikan oleh karyawan Masjid Raya Bintaro. Berdasarkan tinjauan uraian sebelumnya, maka dapat ditarik kesimpulan sebagai berikut :

A. Pelayanan yang baik dapat dinilai dari citra diri yang baik, jika kita memberikan pelayanan yang ramah, makaakan kembali ramah. Kegiatan ini bermaksud untuk memberikan suasana keakraban dan memberikan rasa nyaman terhadap suasanan dan pelayanan diperusahaan maupun kantor. 
B. Tujuan kegiatan ini bertujuan untuk memberikan rasa nyaman dan keakraban, sehingga tidak terjadi kesalahpahaman dalam mengetahui informasi yang diperlukan oleh Jamaah ataupun konsumen tersebut.

C. Dalam pemasukan administrasi keuangan dapat di bukukan untuk laporan keuangan setiap bulannya, dalam pemasukan administrasi yang diterima setiap Infaq Shodaqoh dan Zakat dapat kita saluran disekitar Masjid Raya Bintaro kepada Dhuafa dan Yatim yang membutuhkan atau dapat di salurkan keberbagai daerah yang tertimpah bencana dan membutuhkan bantuan.

\section{DAFTAR PUSTAKA}

Daft, Richarsd L, ( 2006 : 45 ) ,Manajemen Pelayanan . PT. Salemba Empat, Jakarta.

Moenir ( 2005 : 47 ), The management of conflick: Interpretations and Interests in Comperative Perspective, Yale University Press.

Suparlan ( $2000: 35$ ), Asas Manajemen, Jakarta

Maddy ( 2009 : 86 ), Pelayanan Prima, Sixth Edition Jilid 1, Jakarta

Philip Kotler (2006 : 83), Marketing Management, Edition New Jersey: Pearson International Edition-Prentice Hall.

Zeithmal Parasuraman (2006:19). The Behaviorial Consequenses of Service Quality.

Patricia Patton (2004:56 ), Service With Emotional Quetient, Jakarta

Daryanto (2010 : 15), Media Pembelajaran, Yogyakarta: Gaya Media

Grasindo (2015:5), Praktis Menyusun Laporan Keuangan, PT Grasindo, Jakarta 